\title{
SUBSTITUSI TEPUNG CANGKANG KERANG SIMPING (Placuna Placenta) DENGAN TEPUNG TAPIOKA TERHADAP MUTU KERUPUK
}

\author{
Endang Nurliana BR P, S.TP ${ }^{(1)}$ dan Raja Marwita Sari Putri, S.Pi., M.Si ${ }^{(2)}$ \\ ${ }^{(1)}$ Alumni Teknologi Pangan Faperta UNISI \\ ${ }^{(2)}$ Dosen Teknologi Pangan Faperta UNISI
}

\begin{abstract}
Abstrak
Tujuan penelitian ini adalah untuk mengetahui jumlah subtitusitepung cangkang kerang simping dengan tepung tapioka yang tepat dalam pengolahan kerupuk,sehingga menghasilkan mutu yang baik. Berdasarkan hasil penelitian Pengaruh Subtitusi Tepung Cangkang Kerang Simping (Placuna placenta) dengan Tepung Tapioka terhadap Tekstur Kerupuk dapat disimpulkan bahwa perlakuan terbaik adalah :pada perlakuan C (20\% Tepung kerang simping/bb : 47 7\% tepung tapioka/bb) dengan kadar air 2,65 \%, kadar lemak 10,76 \%, kadar protein 8,26 \%, kadar pati 19,39 \%, kadar kalsium 5,22 mg/L.
\end{abstract}

\section{PENDAHULUAN}

Indonesia merupakan salah satu negara yang memiliki kekayaan alam yang sangat berlimpah salah satunya produk perikanan. Salah satu jenis hasil perikanan adalah kerang simping (Placuna placenta), yang ditemukan dalam substrat lumpur dan pasir berlumpur diperairan dangkal. Perairan Indragiri Hilir merupakan salah satu tempat ditemukannya kerang simping ini.

Kerang simping (placuna placenta) yang terdapat di perairan Indragiri Hilir memiliki akan kayanya nilai gizi serta nilai ekonomi baik sebagai kerajinan tangan maupun hanya dikonsumsi masyarakat dalam sehari hari, dimana daging yang memiliki segudang kandungan gizi yang bisa di formulasikan kedalam sejumblah produk olahan pangan, seperti dalam penambahan rasa pada pembuatan amplang (Yuslinawati, 2015). Kandungan kalsium yang terdapat pada cangkang kerang simping (placuna placenta) juga bisa di optimalisasi ke dalam pemanfaatan cangkang pada pembuatan biskuit (Putri et al, 2014).

Cangkang kerang dapat diupayakan dengan memanfaatkan kandungan nutrisi yang ada untuk meningkatkan nilai tambah (added value). Nutrisi cangkang kerang memiliki kandungan mineral terutama kalsium yang cukup tinggi, sehingga diperlukan diversikasi produk yang dapat digunakan sebagai sumber kalsium alami. Upaya dalam pemanfaatan kandungan kalsium dalam cangkang kerang tersebut dapat berupa kerupuk yang diformulasikan dengan tepung cangkang kerang sebagai sumber kalsium alami. Produk diversikasi berupa kerupuk kaya kalsium diharapkan dapat diterima oleh konsumen dari segala usia dan menjadi salah satu solusi dalam mengatasi masalah defisiensi kalsium pada tubuh. Kurangnya konsumsi kalsium akan menyebabkan terjadinya gangguan kesehatan pada manusia (Weaver dan Heaney 1999). Asupan kalisum yang memadai pada masa pertumbuhan sangat penting untuk 
menghasilkan massa tulang yang maksimal sehingga akan mengurang resiko terjadinya gangguan kesehatan seperti osteoporosis (Heaney et al., 2000).

Kerupuk adalah makanan kudapan kering yang bersifat ringandan porous yang terbuat dari bahan yang mengandung pati cukup tinggi dan sangat popular, serta mudah cara pembuatannya, beragam warna dan rasa disukai oleh segala lapisan usia dan seluruh suku di Indonesia. Namun selama ini kerupuk hanya merupakan makanan kudapan tampa memperhatikan nilai gizinya dengan adanya pemanfaatan tepung cangkang kerang simping diharapkan dapat meningkatkan nilai gizi kerupuk.

Tepung cangkang kerang simping yang kaya kalsium adalah hasil olahan cangkang kerang simping yang diproses dengan cara pengeringan, dan dibuat serbuk dengan dihancurkan dan diayak ( Putri ad al, 2014 ). Tepung cangkang kerang simping diharapkan bisa ditambahkan di dalam pengolahan kerupuk dan selama ini kerupuk yang dibuat dari adonantepung tapioka yang dicampur bahan perasa yang selama ini sering ditambahkan seperti udang atau ikan. Alasan mengapa tepung tapioka yang sering digunakan di dalam pengolahan kerupuk karena pati pada tepung tapioka mempunyai kandungan amilopektin lebih tinggi dibandingkan jenis pati yang lain dan ini menyebabkan terjadinya pengembangan yang lebih besar sehingga akan terbentuk tekstur yang lebih renyah (Muchtadi et al., 1988).

Pemanfaatan cangkang kerang simping di Indragiri Hilir sudah ada yang mengembangkan dalam pembuatan biskuit dengan kalsium $7,12 \%$ (Putri et al. 2014) karena cangkang kerang simping mengandung kalsium yang cukup tinggi. Dengan demikian salah satu cara mengembangkan pemamfaatan kandungan kalsium yang cukup tinggi kedalam aneka olahan produk pangan dengan cara mengolahnya menjadi tepung dan dijadikan bahan tambah dalam pengolahan pangan yaitu kerupuk.

Penelitian Lailan ( 2012 ), telah mensubtitusikan tepung cangkang kerang hijau di dalam pembuatan kerupuk dengan subtitusi tepung cangkang kerang hijau (Perna viridis) yang terbaik adalah $10 \%$ menurut penilaian organoleptik dengan persentase bahan yang digunakan adalah tepung tapioka $57 \%$, garam $2,7 \%$, gula, $1,3 \%$, bawang putih $2 \%$, air $27 \%$ dan tepung cangkang kerang hijau $10 \%$.

Masalah utama dalam

pengolahan kerupuk dari tepung cangkang kerang simping adalah belum diketahuinya subtitusi tepung cangkang kerang simping dan kosentrasi tepung tapioka yang tepat untuk menghasilkan mutu kerupuk tinggi kalsium yang menghasilkan mutu kerupuk yang baik, dengan demikian penulis telah melakukan penelitian dengan judul " Substitusi Tepung Cangkang Kerang Simping (Placuna placenta) dengan Tepung Tapioka terhadap Mutu Kerupuk.

\section{Tujuan Penelitian}

Tujuan penelitian ini adalah untuk mengetahui jumlah subtitusitepung cangkang kerang simping dengan tepung tapioka yang tepat dalam pengolahan kerupuk,sehingga menghasilkan mutu yang baik.

\section{ManfaatPenelitian.}

1. Memberikan informasi kepada masyarakat untuk mengolah cangkang kerang simping ke dalam berbagai aneka varian produk olahan pangan. 
2. Sebagai informasi bagi masyarakat di dalam pengolahan cangkang kerang simping menjadi tepung yang dijadikan sebagai bahan tambah pangan di dalam pengolahan kerupuk.

\section{METODOLOGI PENELITIAN}

\section{Bahan}

Bahan yang digunakan dalam penelitian ini adalah tepung cangkang kerang simping (Placuna Placenta), garam, bawang putih, tepung tapioka, minyak goreng dan air. Bahan analisa kimia; Kadar protein : Selenium, $\mathrm{H}_{2} \mathrm{SO}_{4}$ pekat, aquadest, $\mathrm{H}_{2} \mathrm{BO}_{3}, \mathrm{NaOH} 30 \%$. Kadar kalsium : $\mathrm{CaCO}_{3}$, asam nitrat, $\mathrm{HNO}_{3}, \mathrm{HClO}_{4}$ dan $\mathrm{HCl}$

\section{Alat}

Alat yang digunakan dalam pembuatan kerupuk cangkang kerang simping adalah lesung, kompor, panci, blender, ayakan, toples, loyang, kuali dan sendok goreng. Alat yang digunakan untuk analisa kimia adalah spatula, timbangan analitik, thermometer,gelas ukur, labu ukur dll.

\section{Metode Penelitian}

Rancangan percobaan yang digunakan di dalam penelitian"Subtitusi Tepung Kerang Simping (Placuna placenta)dengan Tepung Tapioka Terhadap Kerupuk ini" adalah Rancangan Acak Lengkap (RAL) terdiri dari tiga perlakuan. Total bahan tepung kerang simping dan tepung tapioka yang digunakan adalah $67 \% /$ bb yang diperbandingkan adalah jumlah tepung dengan perlakuan sbb :
$\mathrm{A}=10 \%$ tepung kerang simping/bb : $57 \%$ tepung tapioka/bb

$\mathrm{B}=15 \%$ tepung kerang simping/bb $: 52 \%$ tepung tapioka/bb

$\mathrm{C}=20 \%$ tepung kerang simping/bb :47\% tepung tapioka/bb

Perlakuan ini diulang sebanyak 3 kali sehingga diperoleh pula perlakuan $3 \times 3$ dengan 9 satuan unit percobaan. Model rancangan yang digunakan adalah sebagai berikut :

$Y_{i j}=\mu+P_{i+} E_{i j}$

\section{Keterangan :}

$\mathrm{Y}_{\mathrm{ij}}$ : Hasil Pengamatan terhadap perlakuan persentase konsentrasi tepung cangkang kerang simping dalam pembuatan kerupuk cangkang kerang simping.

$\mu \quad$ : Nilai rata-rata.

$\mathrm{P}_{\mathrm{i}} \quad$ : Pengaruh persentase konsentrasi tepung cangkang kerang simping.

E : Pengaruh sisa pada satuan percobaan yang mendapatkan perlakuan konsentrasi tepung cangkang kerang simping (1-4) pada ulangan (1-3)

i : Perlakuan konsentrasi tepung cangkang kerang simping.

j : Ulangan (1-3)

Hasil data dianalisa secara statistik, jika $\mathrm{F}$ hitung > dari $\mathrm{F}$ tabel, maka dilakukan uji lanjut BNJ taraf nyata 5\%.Kombinasi studi subtitusitepung cangkang kerang simping (Placuna Placenta) dengan tepung tapioka terhadap mutu kerupuk tinggi kalsium.dapat dilihat pada Tabel 1. 
Tabel 1. Kombinasi Perlakuan Subtitusi Tepung Cangkang Kerang Simping pada Pembuatan Kerupuk

\begin{tabular}{|c|c|c|c|}
\hline \multirow{2}{*}{ Ulangan } & \multicolumn{3}{|c|}{ Konsentrasi Tepugn Cangkang Kerang Simping } \\
\cline { 2 - 4 } & $\mathrm{A}(10 \%)$ & $\mathrm{B}(15 \%)$ & $\mathrm{C}(20 \%)$ \\
\hline 1 & $\mathrm{~A} 1$ & $\mathrm{~B} 1$ & $\mathrm{C} 1$ \\
\hline 2 & $\mathrm{~A} 2$ & $\mathrm{~B} 2$ & $\mathrm{C} 2$ \\
\hline 3 & $\mathrm{~A} 3$ & $\mathrm{~B} 3$ & $\mathrm{C} 3$ \\
\hline
\end{tabular}

\section{Pelaksanaan Penelitian}

Proses pembuatan kerupuk cangkang kerang simping terdiri dari dua tahap yaitu pembuatan tepung cangkang kerang simping dan pembuatan kerupuk dari tepung cangkang kerang simping.

\section{Pembuatan Tepung Cangkang Kerang Simping(Sada, 1984 ) yang telah dimodifikasi.}

Proses pembuatan tepung cangkang kerang simping terdiri dari beberapa tahap yaitu : sortasi, pencucian, pengeringan, penghancuran dan pengayakan.

\section{Sortasi}

Sortasi bertujuan untuk cangkang kerang simping yang baik dengam melihat secara visual memperoleh seperti memilih cangkang kerang simping yang bewarna agak putih dan untuk bau tidak terlalu amis.

2. Pencucian

Cangkang kerang simping dicuci dengan menggunakan air mengalir.dengan tujuan untuk menghilangkan kotoran seperti tanah dan untuk menghilangkan bau.

3. Pengeringan

Cangkang kerang simping yang telah bersih dikeringkan dengan suhu 50$60^{\circ} \mathrm{C}$ selama 6-8 jam atau sampai cangkang kerang simping mudah dipatahkan atau rapuh.

4. Penghancuran ( Pengecilan Ukuran ) Cangkang kerang simping kering, kemudian dihancurkan dengan menggunakan lesung. Kemudian dihaluskan dengan blender.

5. Hidrolisis

Hidrolisi dengan menggunakan suhu $50^{\circ} \mathrm{C}$ selama 3 jam dengan menggunakan bahan kimia yaitu $\mathrm{NaOH}(9,5 \mathrm{~N}, 0,10 \mathrm{~N}$ dan $0,15 \mathrm{~N})$

6. Penetralan ( $\mathrm{pH} 7)$

Penetralan dengan melakukan pencucian sehingga diperoleh $\mathrm{pH} 7$

7. Pengeringan Oven

Pengeringan dilakukan pada suhu 121 oC dengan tujuan agar mempermudah proses penggilingan

8. Penggilingan

Penggilingan bertujuan untuk memperkecil ukuran dari cangkang kerang simping menjadi lebih halus sehingga mempermudah peruses pengayakan

9. Pengayakan

Cangkang kerang simping yang telah dihaluskan diayak dengan menggunakan ayakan sederhana dengan menggunakan ukuran ayakan 80 mesh.

\section{Pembuatan Kerupuk Cangkang Kerang Simping (Tababaka, 2004) yang telah dimodifikasi.}

Proses pembuatan kerupuk cangkang kerang simping terdiri dari beberapa tahap yaitu, persiapan bahan, penimbangan, pencampuran, pengadonan, pencetakan dan pemasakan.

\section{Persiapan Bahan}

Bahan yang akan digunakan di dalam pembuatan kerupuk dipersiapkan 
setelah itu bahan-bahan yang akan digunakan.ditimbang sesuai dengan kebutuhan. Bahan yang akan digunakan yaitu tepung cangkang kerang simpingdengan tepung tapioka sesuai perlakuan( a1= tepung cangkang kerang simping $10 \% \mathrm{a} / / \mathrm{bb}$ dengan tepung tapioka $57 \% / \mathrm{bb}, \mathrm{a} 2=$ tepung cangkang kerang simping 15 $\% \mathrm{a} / / \mathrm{bb}$ dengan tepung tapioka 52 $\% / \mathrm{bb}$ dan $\mathrm{a} 3=$ tepung cangkang kerang simping $20 \% \mathrm{a} / \mathrm{/bb}$ dengan tepung tapioka $47 \% / \mathrm{bb} 15 \%$ Pada perlakuan ini jumlah total bahan yang digunakan dalam penelitian adalah 250 gr, dengan persentase berat tepung tapioka dengan tepung cangkang kerang simping total adalah $67 \%$, garam $2,7 \%$, gula 1,3 $\%$, bawang putih $2 \%$ dan air $27 \%$. Dalam peneltian ini yang dipariasikan adalah tepung tapioka dengan tepung cangkang simping.

2. Pencampuran/ Pengadonan

Setelah bahan ditimbang, kemudian bahan dicampur sampai rata sesuai dengan perlakuan sambil diaduk dan diulen sampai adonan homogen,

3. Pemanasan

Kemudian adonan dipanaskan sebagian sampai membentuk gelatinisasi dan kemudian dicampurkan dengan tepung yang sebagian yang tidak dipanaskan. Kemudian dicampurkan sampai terbentuk homogen.

4. Pencetakan

Adonan kemudian dibentuk menjadi silinder (dodolan) dengan panjang 20-25 cm dan diameter $4-5 \mathrm{~cm}$

5. Pengukusan

Kemudian adonan yang telah dibentuk dikukus seperti bentuk dodolan Dodolan dimasukkan dikukus selama 90 menit dan suhu $90{ }^{\circ} \mathrm{C}$ atau sampai bagian dalamnya matang.
6. Pendinginan

Dodolan matang didinginkan di dalam lemari pendingin selama 24 jam sehingga dodol mengeras dan mudah dipotong yang disebut dengan dodolan matang keras.

7. Pengirisan

Dodolan matang keras diiris tipis (2 $\mathrm{mm}$ ) dengan pisau/ parutan sehingga diperoleh kerupuk basah.Kerupuk basah diangin - anginkan.

8. Pengeringan/ Penjemuran

Kerupuk yang telah diiris kemudian dikeringkan dengan oven pada suhu $50 \quad{ }^{\circ} \mathrm{C}$ selama $15-18$ jam. Pada penelitian ini pengeringan dengan melakukan penjemuran dengan sinar matahari sampai kering sampai kerupuk mudah dipatahkan.

9. Penggorengan

Kerupuk mentah digoreng di dalam minyak goreng panas dalam keadaan terendam selama $10-20$ detik sambil dibalik-balik.

\section{HASIL DAN PEMBAHASAN}

\section{Kadar Air}

Kadar air adalah porsentase kandungan air suatu bahan, yang dinyatakan berdasarkan berat basah (wet basis) atau berdasarkan berat kering (dry basis) (Syarief dan Halid, 1991). Kadar air yang didapat dari analisis kerupuk dari perlakuan subtitusi tepung cangkang kerang simping (Placuna Placenta) dengan tepung tapioka terhadap kadar air kerupuk adalah 2,65\%-4,42\%. Kadar air kerupuk ini memenuhi SNI 0272 1990 kerupuk yaitu maksimum $12 \%$.

Hasil analisis sidik ragam terhadap kadar air kerupuk memperlihatkan bahwa pengaruh perlakuan subtitusi tepung cangkang kerang simping dengan tepung tapioka memberikan pengaruh berbeda nyata terhadap kadar air kerupuk menurut uji 
lanjut BNJ pada taraf nyata $5 \%$. Untuk pengaruh subtitusi tepung cangkang

dengan tepung tapioka terhadap kadar air kerang simping (Placuna placenta)

kerupukdapat dilihat pada Tabel 2.

Tabel 2. Pengaruh Subtitusi Tepung Cangkang Kerang Simping (Placuna placenta) dengan Tepung Tapioka terhadap Kadar Air Kerupuk.

\begin{tabular}{|c|cc|}
\hline \multicolumn{2}{|c|}{ Perlakuan } & \multicolumn{3}{|c|}{ Kadar Air (\%) } \\
\hline $\mathrm{A}=10 \%$ Tepung kerang simping/bb : 57\% tepung tapioka/bb & 4,42 & $\mathrm{~A}$ \\
\hline $\mathrm{B}=15 \%$ Tepung kerang simping/bb : $52 \%$ tepung tapioka/bb & 3,08 & $\mathrm{~B}$ \\
\hline $\mathrm{C}=20 \%$ Tepung Kerang Simping/bb:47 \% Tepung Tapioka/bb & 2,65 & $\mathrm{~B}$ \\
\hline Keterangan $\begin{array}{c}\text { : Angka-angka pada jalur atau kolom yang sama diikuti oleh huruf } \\
\text { berbeda nyata menurut uji lanjut Tukey pada taraf nyata 5\%. }\end{array}$ & sama \\
\hline
\end{tabular}

Dari Tabel 2 dapat dilihat bahwa nilai tertinggidiperoleh pada perlakuan $\mathrm{A}$ (10\% Tepung kerang simping/bb : 57\% tepung tapioka/bb) yaitu $4,42 \%$ dan yang terendah pada perlakuan C (20\% Tepung Kerang Simping/bb : $47 \%$ Tepung Tapioka/bb) yaitu 2,65 \%. Dari Tabel 2 menunjukan bahwa semakin tinggi subtitusi tepung cangkang kerang simping dan semakin rendah penambahan tepung tapioka di dalam pengolahan kerupuk akan diiringi dengan penurunan kadar air kerupuktinggi kalsium. Banyak faktor yang mempengaruhi jumIah kadar air pada perlakuan subtitusi tepung cangkang kerang simping (Placuna placenta) dengan tepung tapioka terhadap kerupuk, diantara faktor tersebut adalah kandungan kadar air dari bahan baku yang digunakan berbeda, kandungan kadar air dari tepung cangkang kerang simping yaitu $0,18 \%$ (Putriet al., 2014) dan tepung tapioka 14 $\%$ - $15 \%$ (SNI, 2008 ) serta persentase jumlahbahan baku yang digunakan di dalam pengolahan. Perbedaan persentase jumlah tepung yang digunakan dimana semakin meningkat porsentase subtitusi tepung cangkang kerang simping dan menurunnya porsentase tepung tapioka yang digunakan maka kadar air kerupuk kerang simping menurun.

Menurut Winarno (2002), semua bahan makanan mengandung air dalam jumlah yang berbeda - beda, baik itu bahan makanan hewani maupun nabati. Perbedaan kandungan kadar air ini akan mempengaruhi kandungan air dari hasil olahan pangan.

Selain itu sifat bahan baku yang digunakan di dalam pengolahan kerupuk tinggi kalsium juga memegang peranan penting dalam penentuan kadar air dari kerupuk. Disamping itu sifat dari tepung berfungsi sebagai pengikat yang mengikat daya kadar air, dimana tepung akan mengikat air yang berada dalam pengolahan/ matrik, sehingga kadar air matrik menurun dan penurunan ditentukan dengan jumlah persentase tepung yang ditambahkan. Hal ini sesuai dengan pernyataan (Manullang et al. 1995) yang menyatakan penurunan kadar air akibat mekanisme interaksi pati dan protein sehingga air tidak dapat diikat secara sempurna karena ikatan hidrogen yang seharusnya mengikat air telah dipakai untuk interaksi pati dan protein. Dengan demikian semakin tinggi persentase tepung tapioka yang digunakan maka massa tepung tapioka dalam kerupuk akan semakin besar.

Ernawati (2003), menyatakan bahwa tepung tapioka mengandung amilosa $17 \%$ dan amilopetin $83 \%$ dengan ukuran granula 3-35 $\mu \mathrm{m}$. Selisih antara amilosa dan amilopektin yang 
cukup tinggi ini, menyebabkan proses penyerapan air selama pemasakan cukup tinggi. Berdasarkan besar kecilnya air yang diserapdalam granula pati, akan menentukan daya kembang pada saat pemasakan. Semakin tinggi air terikat, semakin besar pula daya kembangnya

\section{Kadar Protein}

Protein merupakan suatu zat makanan yang sangat penting bagi tubuh, karena zat ini disamping berfungsi sebagai bahan bakar dalam tubuh juga berfungsi sebagai zat pembangun dan pengatur. Protein adalah sumber asam-asam amino yang mengandung unsur-unsur $\mathrm{C}, \mathrm{H}, \mathrm{O}$, dan $\mathrm{N}$ yang tidak dimiliki oleh lemak atau karbohidrat. Molekul protein mengandung pula fosfor, belerang, dan ada jenis protein yang mengandung unsur logam seperti besi dan tembaga (Winarno, 2002).

Hasil analisis sidik ragam terhadap kadar protein kerupuk memperlihatkan bahwa pengaruh perlakuan subtitusi tepung cangkang kerang simping dengan tepung tapioka memberikan pengaruh tidak berbeda nyata terhadap kadar protein kerupuk menurut uji lanjut BNJ pada taraf nyata $5 \%$. Untuk pengaruh subtitusi tepung cangkang kerang simping (Placuna placenta) dengan tepung tapioka terhadap mutu kerupuk terhadap kadar protein kerupuk dapat dilihat pada Tabel 3.

Tabel 3. Pengaruh Substitusi Tepung Cangkang Kerang Simping (Placuna placenta) dengan Tepung Tapioka terhadap Kadar Protein Kerupuk.

\begin{tabular}{|c|l|}
\hline \multicolumn{1}{|c|}{ Perlakuan } & Kadar Protein $(\%)$ \\
\hline $\mathrm{C}=20 \%$ Tepung kerang simping/bb : 47\% tepung tapioka/bb & 8,26 \\
\hline $\mathrm{B}=15 \%$ Tepung kerang simping/bb $: 52 \%$ tepung tapioka/bb & 7,90 \\
\hline $\mathrm{A}=10 \%$ Tepung kerang simping/bb $: 57 \%$ tepung tapioka/bb & 6,99 \\
\hline
\end{tabular}

Dari Tabel 3 dapat dilihat bahwa nilai tertinggi untuk kadar protein diperoleh pada perlakuan C (20\% Tepung kerang simping/bb : 47\% tepung tapioka/bb) yaitu $8,26 \%$ dan yang terendah pada perlakuan A $(10 \%$ Tepung Kerang Simping/bb : $57 \%$ Tepung Tapioka/bb) yaitu 6,67 \%., namun dari semua perlakuan tidak memberikan pengaruh berbeda nyata menurut uji lanjut BNJ pada taraf nyata $5 \%$.

Dari Tabel 3 menunjukan bahwa semakin tinggi subtitusi tepung cangkang kerang simping dan semakin rendah penambahan tepung tapioka di dalam pengolahan kerupuk akan menyebabkan kadar protein kerupuk akan menikat. Faktor yang mempengaruhi jumlah kadar protein pada perlakuan subtitusi tepung cangkang kerang simping dengan tepung tapioka bahwa bahan baku yang digunakan yaitu tepung cangkang kerang simping dengan tepung tapioka mempunyai kadar protein yang berbeda, kadar protein tepung cangkang kerang simping 11,20\% (Haryonoet al., 2013) dan tepung tapioka $1,50 \%$ ( SNI, 2008), perbedaan kadar protein dari bahan baku akan menyebabkan kadar protein dari kerupuk tinggi kalsium akan berbeda, semakin meningkatnya jumlah subtitusi tepung cangkang kerang siping maka kadar protein semakin meningkat. Kadar protein untuk kerupuk dari semua perlakuan memenuhi standarmutu kerupuk menurut SNI 0272 - 1990 yaitu minimum $5 \%$.

Dari tabel 3 dapat dilihat bahwa 
antara semua perlakuan untuk kadar protein tidak berbeda nyata menurut uji lanjut BNJ pada taraf nyata $5 \%$. Hal ini disebabkan karena adanya pengaruh dari suhu yang digunakan selama pengolahan yang dapat menyebabkan denaturasi protein. Menurut Matias (2011), Protein pangan terdenaturasi jika dipanaskan pada suhu moderat $80{ }^{\circ} \mathrm{C}-90{ }^{\circ} \mathrm{C}$ selama 1 jam atau lebih. Denaturasi adalah perubahan strukturprotein dimana pada keadaan terdenaturasi penuh hanya struktur primer aja yang tersisa. Protein tidak lagi memiliki struktur sekunder, tersier dan kuartener.

\section{Kadar Lemak}

Winarno (2002) menyatakan bahwa Lemak dan minyak merupakan zat makanan yang penting untuk menjaga kesehatan tubuh manusia. Selain itu lemak juga merupakan sumber energi yang lebih efektif dibandingkan dengan karbohidrat dan protein. Kadar lemak kerupuk sangat ditentukan oleh absorbsi minyak yang dihasilkan dari proses penggorengan. Absorbsi minyak yang tinggi oleh produk pangan selain mudah menyebabkan ketengikan juga tidak disukai oleh konsumen terutama yang mehindari makanan dengan kadar lemak tinggi. Pada proses penggorengan, air akan mengalami penguapan dan membentuk rongga yang dapat terisi minyak (Herlina, 1999).

Hasil analisis sidik ragam terhadap kadar lemak kerupuk tinggi kalsium memperlihatkan bahwa pengaruh perlakuan subtitusi tepung cangkang kerang simping dengan tepung tapioka memberikan pengaruh berbeda nyata terhadap kadar lemak kerupuk menurut uji lanjut BNJ pada taraf nyata $5 \%$. Untuk pengaruh subtitusi tepung cangkang kerang simping (Placuna placenta) dengan tepung tapioka terhadap kadar lemak kerupuk dapat dilihat pada Tabel 4.

Tabel 4. Pengaruh Subtitusi Tepung Cangkang Kerang Simping (Placuna placenta) dengan Tepung Tapioka terhadap Kadar Lemak Kerupuk

\begin{tabular}{|c|c|}
\hline Perlakuan & Kadar Lemak (\%) \\
\hline $\mathrm{A}=10 \%$ Tepung kerang simping/bb $: 57 \%$ tepung tapioka/bb & $12,20 \mathrm{~A}$ \\
\hline $\mathrm{B}=15 \%$ Tepung kerang simping/bb $: 52 \%$ tepung tapioka/bb & $11,56 \mathrm{~A}$ \\
\hline $\mathrm{C}=20 \%$ Tepung kerang simping/bb $: 47 \%$ tepung tapioka/bb & 10,76 \\
\hline
\end{tabular}

Keterangan : Angka-angka pada jalur atau kolom yang sama diikuti oleh huruf yang sama berbeda nyata menurut uji lanjut Tukey pada taraf nyata $5 \%$.

Dari Tabel 4 terlihat bahwa kadar lemak yang tertinggi diperoleh pada perlakuan A $(10 \%$ Tepung kerang simping/bb : $57 \%$ tepung tapioka/bb) yaitu $12.20 \%$ dan terendah pada perlakuan C $(20 \%$ Tepung kerang simping/bb : $47 \%$ tepung tapioka/bb) yaitu $10,76 \%$, dimana semakin menurunya subtitusi tepung cangkang kerang simping dan semakin menikatnya penambahan tepung tapioka di dalam pengolahan kerupuk akan diikuti dengan peningkatan kadar lemak dari kerupuk. Hal ini dikarenakan tepung tapioka mengandung pati yang tinggi dan di dalam proses pengolahan akan mengikat air. Semakin tinggi jumlah tepung tapioka yang ditambahkan di dalam pengolahan kerupuk tinggi kalsium maka kadar air yang terikat semakin tinggi. Di dalam proses penggorengan kadar air akan teruapkan karena panas dan rongga yang kosong dari penguapan air akan diisi dengan minyak. Semakin 
tinggi persentase tepung tapioka di dalam pengolahan maka air yang terikat semakin tinggi maka disaat penggorengan maka air yang teruapkan semakin tinggi dan rongga dari penguapan akan diisi dengan minyak maka kandungan lemak/ minyak pada kerupuk semakin tinggi. Ini sesuai menurut (Soeparno, 2003), bahwa kadar lemak produk olahan meningkat seiring dengan peningkatan penambahan tepung.

Weiss (1983), di dalam proses penggorengan sebagian air akan menguap dan ruang kosong yang semula diisi air akan diisi oleh minyak.Kandungan kadar lemak dari kerupuk tinggi kalsium ini cukup rendah dibandingkan sarat mutu kerupuk goreng (per 100 g/bahan) yaitu 30,87 \% (Nurhayati, 2007).

Tepung tapioka mengandung amilosa $17 \%$ dan amilopetin $83 \%$ dengan ukuran granula 3-3,5 jam. Selisih antara amilosa dan amilopektin yang cukup tinggi ini, menyebabkan proses penyerapan air selama pemasakan cukup tinggi. Berdasarkan besar kecilnya air yang diserap dalam granula pati, akan menentukan daya kembang pada saat pemasakan. Semakin tinggi air terikat, semakin besar pula daya kembangnya.

Semakin besar proporsi tapioka, semakin besar pula pengembangannya yang disebabkan amilopektin kurang kuat menahan masa yang genting pada saat penggorengan sehingga air semakin mudah teruapkan. Lebih lanjut dikatakan oleh (Muchtadi et al1988) bahwa kandungan amilopektin yang tinggi akan menikatkan kemampuan mengikat air lebih besar sehingga mempengaruhi tekstur bersifat ringan, garing dan ringan.

\section{Kadar Pati}

Hasil analisis sidik ragam terhadap kadar pati kerupuk tinggi kalsium memperlihatkan bahwa pengaruh perlakuan subtitusi tepung cangkang kerang simping dengan tepung tapioka memberikan pengaruh berbeda nyata terhadap kadar pati kerupuk menurut uji lanjut BNJ pada taraf nyata $5 \%$. Untuk pengaruh subtitusi tepung cangkang kerang simping (Placuna placenta) dengan tepung tapioka terhadap kadar pati kerupuk dapat dilihat pada Tabel 5.

Tabel 5. Pengaruh Subtitusi Tepung Cangkang Kerang Simping (Placuna placenta) dengan Tepung Tapioka terhadap Kadar Pati Kerupuk

\begin{tabular}{|l|lc|}
\hline \multicolumn{2}{|c|}{ Perlakuan } & \multicolumn{2}{|c|}{ Kadar Pati (\%) } \\
\hline $\mathrm{A}=10 \%$ Tepung kerang simping/bb : 57\% tepung tapioka/bb & $22,94 \quad \mathrm{~A}$ \\
\hline $\mathrm{B}=15 \%$ Tepung kerang simping/bb : 52 \% tepung tapioka/bb & 22,19 & $\mathrm{AB}$ \\
\hline $\mathrm{C}=20 \%$ Tepung kerang simping/bb : 47\% tepung tapioka/bb & 19,39 & $\mathrm{~B}$ \\
\hline
\end{tabular}

Keterangan : Angka-angka pada jalur atau kolom yang sama diikuti oleh huruf yang sama berbeda nyata menurut uji lanjut Tukey pada taraf nyata 5\%.

Dari Tabel 5 dapat dilihat bahwa nilai tertinggi diperoleh pada perlakuan A (10 \% Tepung kerang simping/bb $: 57 \%$ tepung tapioka/bb) yaitu $22,94 \%$ dan yang terendah pada perlakuan C (20 $\%$ Tepung Kerang Simping/bb : $47 \%$ Tepung Tapioka/bb) yaitu $19,39 \%$.
Dari Tabel 5 terlihat bahwa semakin rendahsubtitusi tepung cangkang kerang simping dan semakin menikat tepung tapioka di dalam pengolahan kerupuk akan diikuti dengan penikatan kadar pati dari kerupuk. Hal ini dikarenakan kadar pati dari tepung tapioka sangat tinggi 
yaitu $81 \%-84 \%$ (SNI, 2008) sehingga peningkatan porsentase tepung tapioka akan diiringi juga dengan peningkatan kandungan pati dari kerupuk.

Pati memegang peranan penting di dalam pengembangan produk olahan gorengan. Pati yang banyak mengandung amilopektin (amilosa rendah) tidak membentuk gel yang kukuh. Pada saat pengembangan waktu pengembangan penggorengan setelah gel tersebut kering mempunyai kecenderungan merenggang dari pada patah sehingga tingkat pengembangan lebih besar (Matz, 1976).

\section{Kadar Kalsium}

Kalsium adalah mineral yangpenting bagi manusia, antara lain bagi metabolisme tubuh, penghubung antar saraf, kerja jantung, dan pergerakan otot. Kurangnya konsumsi kalsium akan menyebabkan terjadinya gangguan kesehatan pada manusia (Weaver dan Heaney 1999). Asupan kalisum yang memadai pada masa pertumbuhan sangat penting untuk menghasilkan massa tulang yang maksimal sehingga akan mengurang resiko terjadinya gangguan kesehatan seperti osteoporosis (Heaney et al., 2000). Hasil analisis sidik ragam terhadap kadar kalsium kerupuk memperlihatkan bahwa pengaruh perlakuan subtitusi tepung cangkang kerang simping dengan tepung tapioka memberikan pengaruh berbeda nyata terhadap kadar pati kerupuk menurut uji lanjut BNJ pada taraf nyata $5 \%$. Untuk pengaruh subtitusi tepung cangkang kerang simping (Placuna placenta) dengan tepung tapioka terhadap. Kadar kalsium kerupuk dapat dilihat pada Tabel 6.

Tabel 6. Pengaruh Subtitusi Tepung Cangkang Kerang Simping (Placuna placenta) dengan Tepung Tapioka terhadap Kadar Kalsium Kerupuk.

\begin{tabular}{|l|lc|}
\hline \multicolumn{2}{|c|}{ Perlakuan } & \multicolumn{2}{|l|}{ Kalsium (mg/L) } \\
\hline $\mathrm{C}=20 \%$ Tepung kerang simping/bb :47\% tepung tapioka/bb & $5,22 \quad \mathrm{~A}$ \\
\hline $\mathrm{B}=15 \%$ Tepung kerang simping/bb $: 52 \%$ tepung tapioka/bb & 3,73 & $\mathrm{~B}$ \\
\hline $\mathrm{A}=10 \%$ Tepung kerang simping/bb $: 57 \%$ tepung tapioka/bb & $2,74 \quad \mathrm{C}$ \\
\hline
\end{tabular}

Keterangan : Angka-angka pada jalur atau kolom yang sama diikuti oleh huruf yang sama berbeda nyata menurut uji lanjut Tukey pada taraf nyata 5\%.

Dari Tabel 6 dapat dilihat bahwa nilai tertinggi kalsium diperoleh pada perlakuan C (20 \% Tepung kerang simping/bb : $47 \%$ tepung tapioka/bb) yaitu $5,22 \mathrm{mg} / \mathrm{L}$. dan yang terendah pada perlakuan A (10 \% Tepung Kerang Simping/bb : $57 \%$ Tepung Tapioka/bb) yaitu 2,74 mg/L. Dari Tabel 6 terlihat bahwa dari perlakuan A sampai perlakuan $\mathrm{C}$, dimana semakin rendah subtitusi tepung cangkang kerang simping dan semakin menikatnya tepung tapioka di dalam pengolahan kerupuk tinggi kalsium akan diikuti dengan penurunan kadar kalsium dari kerupuk.
Hal ini disebabkan kandungan kalsium dari tepung cangkang kerang simping cukup tinggi sehingga peningkatan subtitusi tepung cangkang kerang simping akan menikatkan kandungan kalsium sedangkan kadar kalsium dari tepung tapioka yaitu $45,60 \mathrm{mg} / 100 \mathrm{~g}$ ( SNI, 2008 ).

Menurut Putriet al., (2014), kadar abu yaitu tepung cangkang kerang simping (placuna placenta) sebesar $62,42 \%$, kadar abu tepung cangkang kerang simping ini lebih tinggi dari pada kadar abu cangkang rajungan, standar yang ditetapkan BBPMHP (2000) untuk 
kadar abu cangkang rajungan adalah $55,21 \%$. Besarnya kadar abu pada tepung cangkang kerang simping menunjukkan tingginya kandungan mineral pada cangkang kerang terutama kalsium.

\section{KESIMPULAN DAN SARAN}

\section{Kesimpulan}

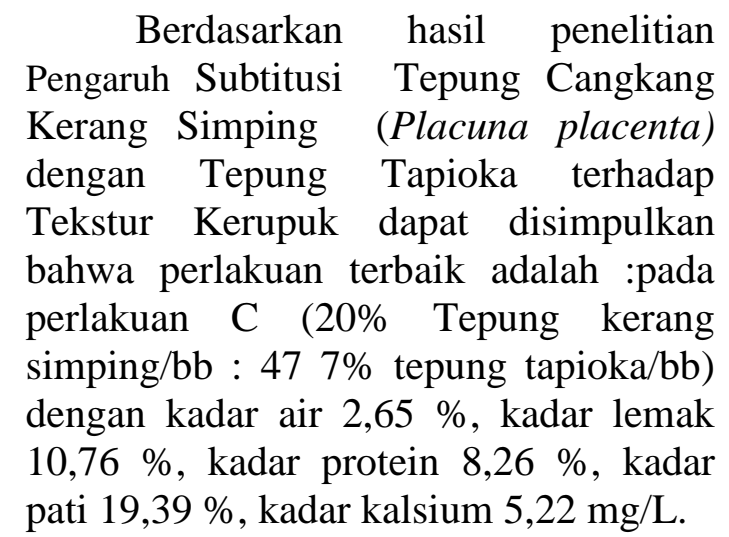

\section{Saran}

Diharapkan kedepannya penggunaan tepung cangkang kerang simping dapat digunakan sebagai bahan baku pengganti tepunglain nya untuk pengolahan produk pangan.

\section{DAFTAR PUSTAKA}

Apriyantono, A., 2006. Bahan Pembuat Bakery dan Kue. http://dunia.pelajar-islam.or.id. Akses tanggal 6 desember 2014.

Astawan ,Made. Tepung Terigu. 2004. Dan Nasi http://www.gizi.net Diakses tanggal 10 januari 2014.

Buckle, K.A., R.A. Edwards, G.H. Fleet and M. Wootton, 1987. Ilmu Pangan. Penerjemah H. Purnomo dan Adiono.UI-Press, Jakarta.

Dep. Perindustrian. 1990. Standar Industri Indonesia (SII). Standar Mutu Biskuit (SII 0177 - 90). 1990. Akses tanggal 27 November 2014.
Ernawati. 2003. Kelebihan Tepung Tapioka. http//www.Pustaka. iptek.com. Diakses 14 Oktober 2014.

Fellow, J,J. 1990. Food Processing Teknology, Principle and Practise. Ellis Horwood. London.

Gaman, P, M dan K,B, Sherington, 1992. Pengantar Ilmu Pangan Nutrisi dan Mikrobiologi Terjemahan M, Gardjito, S, Naruki, A, Murdiati, Sardjono.Gajah Mada University Press. Yogyakarta.

Haryono I, Agustin TW., danA.D Anggo. (2013) Karakteristik Tepung Cangkang Kerang Simping (Amusium pleuronectes) dengan Waktu yang Berbeda. Jurnal Pengolahan Bioteknologi Hasil Perikanan. Vol 2 . No 31

Heaney RP, Abrams S, Dawson-Hughes B, Looker A, Marcus R, Matkovic V. 2000. Peak bone mass. Osteoporosis International, 11, 985-1009

Hiswaty. 2002. Pengaruh Penambahan Tepung ikan Nila Merah (Oreochromus sp) terhadap Karakteristik Biskuit. Teknologi Hasil Pertanian. Fakultas Perikanan dan Ilmu Kelautan. IPB, Bogor.

Lailatul, F. 2013. Kerupuk dengan Subtitusi Tepung Cangkang Kerang Hijau (Perna viridis) Menggunakan Metode Boling Steaming sebagai Makanan Berkalsium. Skripsi Fakultas Teknik UM

Matz, S.A. 1976. Snack Food Technologi. AVI. Westport.

Munandar, Aliem Iskak. 1995. Teori Pastry. Yogyakarta : Akademi Kesejahteraan Sosial Tarakanita Yogyakarta. 
Muchtadi.T.R. Purwiyatnodan A. Soekarto, S.T., 1985. Penelitian Basuki. 1988. Teknologi Organoleptik. Pusat Pemasakan Ekstrusi. .PAU.IPB. Pengembangan Teknologi Pangan. Bogor

IPB, Bogor.

Putri, Rms 2014, Mardeschi. H. Nuroso. Sunaryo E, 1985. Pengolahan Produk A. Dosen Pemula. Opitimalisasi Pemanfaatan Cangkang Kerang Simping (Placuna Plancenta) dalam Pembuatan Biskuit. Laporan Akhir Penelitian.

Sihombing, M. 2013. Kerang Simping (Placuna sp.). blogspot.com. Diakses tanggal 17 juni 2015.

Smith. W. H. 1972. Biscuit, Crackers and Cookies Technology Production and Management. London : Aplied Science Publisher : LTD. Serealia dan Biji-bijian. Jurusan Teknologi Pertanian. Institut Pertanian Bogor.

Tababaka, 2004. Pembuatan Kerupuk Cangkang Kerang Simping yang telah Dimodifikasi.

Winarno, F.G. 2004. Kimia Pangan dan Gizi. Jakarta : Gramedia. Pengolahan. Universitas Gadjah Mada. Yogyakarta.

Whitely PR. 1971. Biskuit Manufacture. Applied Science Publishing, Ltd. London. 